Farmers' livelihood strategies and perceived constraints from the poor and nonpoor households: A dataset from a field survey in Nghe An, Vietnam

Quan-Hoang Vuong, Phu Pham, My-Hien Nguyen, Cong-Thang Ngo, Phuong-Mai Tran \& Quy Khuc

Un-peer-reviewed manuscript version 1.3

January 25, 2021

Hanoi, Vietnam 


\title{
Farmers' livelihood strategies and perceived constraints from the poor and non-poor households: A dataset from a field survey in Nghe An, Vietnam
}

\author{
Quan-Hoang Vuong ${ }^{a}$, Phu Pham ${ }^{b, c}$, My-Hien Nguyen ${ }^{c, d}$, \\ Cong-Thang Ngoc,d, Phuong-Mai Trance, Quy Khucc, f
}

a Centre for Interdisciplinary Social Research, Phenikaa University, Hanoi 100000, Vietnam

b Department of Insect Systematics, The Institute Of Ecology and Biological Resources, Hanoi 100000, Vietnam

'Vietkaplab, Vietkap group, Hanoi 100000, Vietnam

d Department of Economics, National Economic University, Hanoi 100000, Vietnam

e Department of International Business, Foreign Trade University, Hanoi 100000, Vietnam

${ }^{\mathrm{f}}$ Faculty of Economics and Business, Phenikaa University, Hanoi 12116, Vietnam

Corresponding author. Emails: quy.khucvan@phenikaa-uni.edu.vn. Address: Room 305, Building A2, Phenikaa University, Ha Dong district, Hanoi, Vietnam.

\section{ABSTRACT}

The first Sustainable Development Goals (SDGs) aims to "end poverty in all its forms everywhere". Its seven associated targets aim, among others, to eradicate extreme poverty for 
all people everywhere. In Vietnam, poverty eradication in ethnic minorities and mountainous areas are among the top priority strategies. This study aims to learn about farmers' livelihood associated with perceived difficulties in Chau Thai Commune, Nghe An Province - a rural mountainous area in Vietnam. A random sampling technique and a face-to-face interview method were employed to survey 215 households in the region in 2018 . The dataset presents that Chau Thai Commune's economic growth largely depends on livestock and forestry. Plantation forests is a major source of income while its area account for about $90 \%$ of household's land. Besides, the livelihood capital disparity in forestland, labor and income between the poor and non-poor households is reported. Therefore, the primary data could be useful for many scholars who want to conduct a further in-depth study and or agricultural economists, policymakers who work on the 'New Rural Development' program to devise a better rural livelihood-improving policy for farmers, particularly the poor in the uplands of Vietnam and beyond.

Keywords: rural livelihood, plantation forests, primary data, sustainable rural development, Vietnam

\section{Data description}

Forests offers a vital role in people's livelihoods, especially for poor people living in remote and upland areas. The acceleration in forest development in Nghe An - a province endowed with biodiversity and high potential forestland for afforestation and reforestation, has attracted substantial investment in climate change mitigation projects, curbing emission [1-5]. Living in a 
poor, mountainous commune, the indigenous people's income largely depends on agricultural production and forest and non-timber forest products (NTFPs) [6,7]. Thus, Chau Thai is chosen as the study region. In 2018, 215 households living within 4 villages were surveyed through a questionnaire consisting of 62 items.

After eliminating some incomplete and highly implausible answers, our raw data includes 215 observations and focus on three aspects: (1) resource structure and the local's livelihood strategies, (2) factors hindering production forest planting, (3) the difference between poor and non-poor households, and (4) the personal information of the head of households. The findings associated with data of our research aims to facilitate policymakers and governments to devise a better sustainable economic development policy in Vietnam and other places in the world. Following are brief results of the research.

Table 1. Land use, income structure, and livelihood strategies

\begin{tabular}{|c|c|c|c|c|c|c|c|c|c|c|}
\hline \multicolumn{2}{|c|}{ Farmers' livelihood strategies } & \multirow{3}{*}{\begin{tabular}{|l} 
\\
\\
\\
\\
215
\end{tabular}} & \multirow{3}{*}{$\begin{array}{l}\text { Mean } \\
3.15\end{array}$} & \multirow{3}{*}{$\begin{array}{l}\text { Std. } \\
\text { Devia } \\
\text { tion } \\
\\
2.86\end{array}$} & \multirow{3}{*}{$\begin{array}{l}\text { Std.Er } \\
\text { ror } \\
0.20\end{array}$} & \multirow{3}{*}{$\begin{array}{l}\text { Min } \\
\\
0.11\end{array}$} & \multicolumn{2}{|c|}{$\begin{array}{l}95 \% \text { Confidence } \\
\text { Interval for Mean }\end{array}$} & \multirow{3}{*}{$\begin{array}{l}\text { Max } \\
\\
12.45\end{array}$} & \multirow{3}{*}{$\begin{array}{l}\text { Range } \\
\\
12.34\end{array}$} \\
\hline & & & & & & & \multirow{2}{*}{$\begin{array}{l}\begin{array}{l}\text { Lower } \\
\text { Bound }\end{array} \\
2.77\end{array}$} & \multirow{2}{*}{$\begin{array}{l}\begin{array}{l}\text { Upper } \\
\text { Bound }\end{array} \\
3.54\end{array}$} & & \\
\hline Land & Total area (ha) & & & & & & & & & \\
\hline & $\begin{array}{l}\text { Wet rice land area } \\
\text { (ha) }\end{array}$ & 215 & 0.09 & 0.06 & 0.00 & 0.00 & 0.09 & 0.10 & 0.44 & 0.44 \\
\hline & $\begin{array}{l}\text { Paddy rice land area } \\
\text { (ha) }\end{array}$ & 215 & 0.01 & 0.15 & 0.01 & 0.00 & -0.01 & 0.03 & 2.00 & 2.00 \\
\hline & $\begin{array}{l}\text { Shifting cultivation } \\
\text { land area (ha) }\end{array}$ & 215 & 0.01 & 0.10 & 0.01 & 0.00 & 0.00 & 0.02 & 1.00 & 1.00 \\
\hline & $\begin{array}{l}\text { Garden land area } \\
\text { (ha) }\end{array}$ & 215 & 0.01 & 0.03 & 0.00 & 0.00 & 0.01 & 0.02 & 0.23 & 0.23 \\
\hline
\end{tabular}




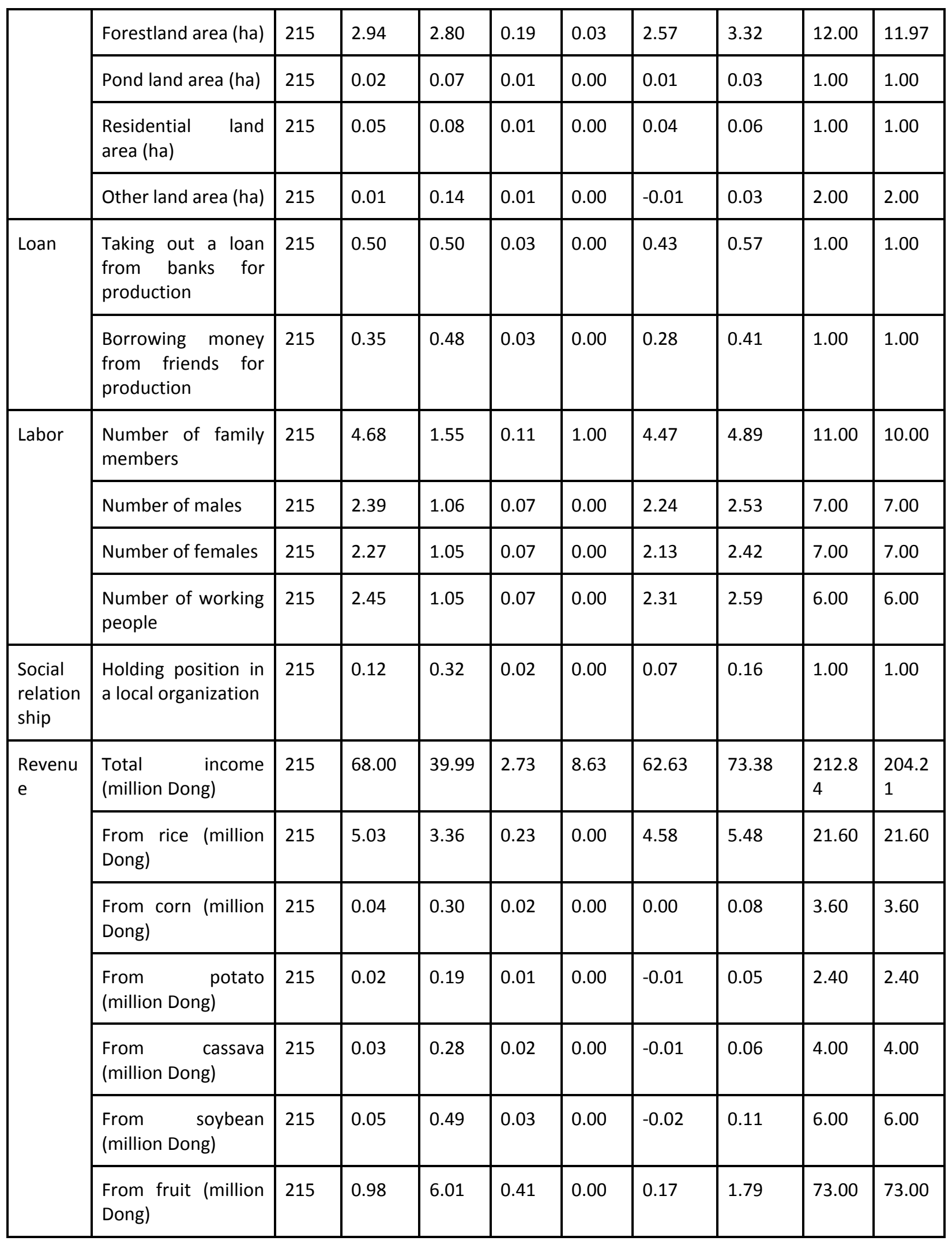




\begin{tabular}{|l|l|l|l|l|l|l|l|l|l|l|}
\hline $\begin{array}{l}\text { From livestock } \\
\text { (million Dong) }\end{array}$ & 215 & 17.24 & 17.55 & 1.20 & 0.00 & 14.88 & 19.60 & $\begin{array}{l}112.5 \\
0\end{array}$ & $\begin{array}{l}112.5 \\
0\end{array}$ \\
\hline $\begin{array}{l}\text { From seafood } \\
\text { (million Dong) }\end{array}$ & 215 & 0.44 & 1.48 & 0.10 & 0.00 & 0.24 & 0.64 & 10.50 & 10.50 \\
\hline $\begin{array}{l}\text { From forest (million } \\
\text { Dong) }\end{array}$ & 215 & 14.67 & 15.18 & 1.04 & 0.00 & 12.63 & 16.71 & 83.33 & 83.33 \\
\hline $\begin{array}{l}\text { From NTFPs (million } \\
\text { Dong) }\end{array}$ & 215 & 0.03 & 0.41 & 0.03 & 0.00 & -0.03 & 0.08 & 6.00 & 6.00 \\
\hline $\begin{array}{l}\text { From wages } \\
\text { (labour) (million } \\
\text { Dong) }\end{array}$ & 215 & 26.55 & 29.84 & 2.04 & 0.00 & 22.53 & 30.56 & 144.0 & 144.0 \\
\hline $\begin{array}{l}\text { From doing } \\
\text { business (million } \\
\text { Dong) }\end{array}$ & 215 & 0.85 & 5.98 & 0.41 & 0.00 & 0.05 & 1.65 & 72.00 & 72.00 \\
\hline $\begin{array}{l}\text { From official salary } \\
\text { (million Dong) }\end{array}$ & 215 & 1.01 & 7.40 & 0.50 & 0.00 & 0.02 & 2.01 & 96.00 & 96.00 \\
\hline $\begin{array}{l}\text { From pension } \\
\text { (million Dong) }\end{array}$ & 215 & 1.08 & 7.06 & 0.48 & 0.00 & 0.13 & 2.03 & 78.00 & 78.00 \\
\hline
\end{tabular}

Note: 1 million VND is equivalent to 43.8 USD (as of February 2018) 


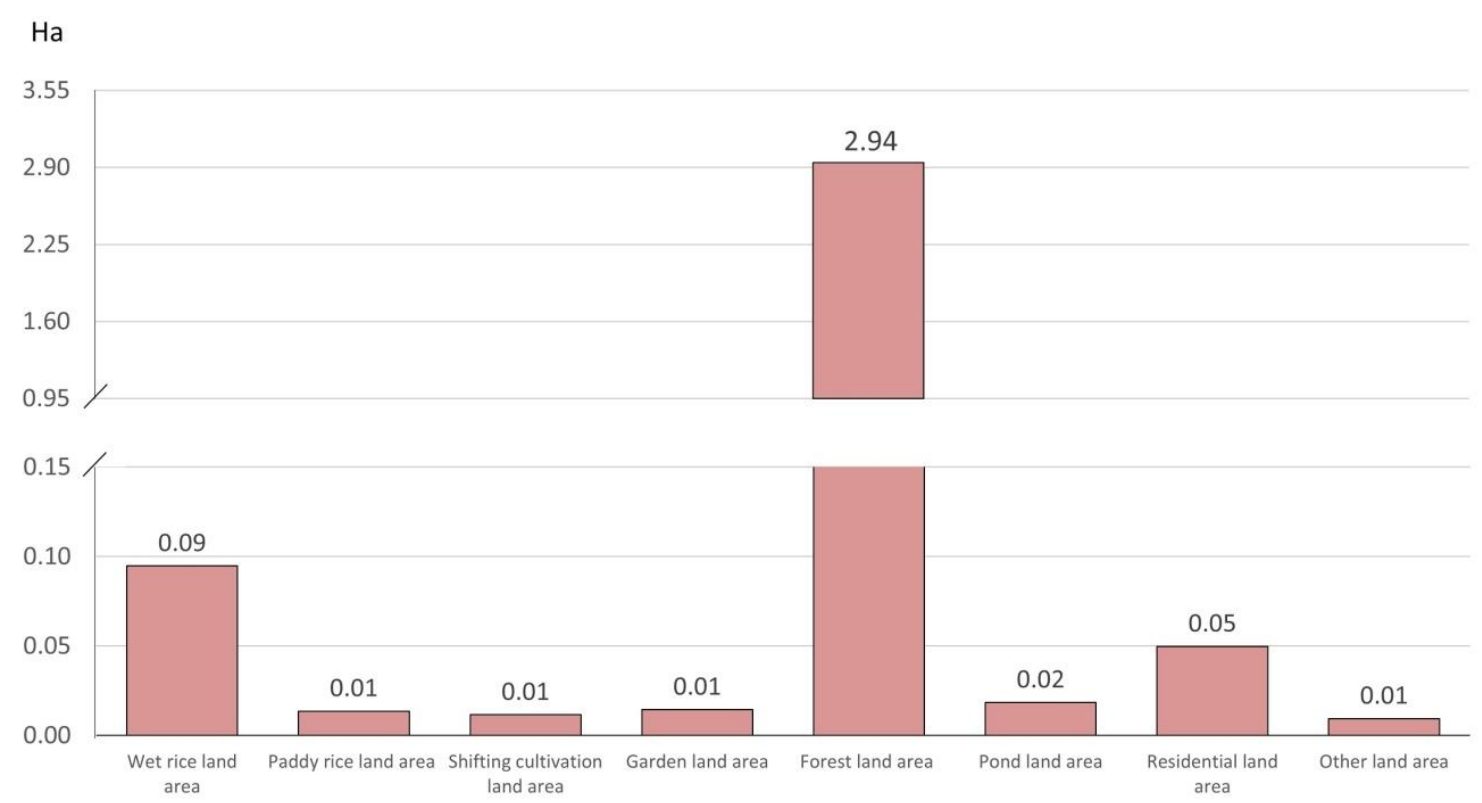

Figure 1. Land use types of households in Chau Thai Commune

Table 1 presents the distribution of economic factors amongst households in Chau Thai, Nghe An. Most of the households' land area is forestland, accounting for over $90 \%$ (Figure 1). Revenue from forestland exploitation in the form of livestock farming and afforestation were dominant income source for the households. Specifically, on average, the revenue of livestock and plantation forests were VND17.24 million and VND14.67 million, respectively, ranking second and third, whereas wages were recoded to the dominant source of household income (VND26.55 million). However, the status of forestland ownership varied widely for the difference of land possession was 12.34 hectares. In addition, the loan policies in Chau Thai exerted a considerable influence on the locals, with roughly $50 \%$ of whom took out loans. The number of people in a family also played a significant part in livelihood strategies. The average number of members was 
4 , while the average labour force was 2.45 , that is, on average, one person would have to feed another. Besides, a relatively gender-balanced workforce was recorded. However, the income inequality was marked when the disparity between the richest and poorest households was VND204.21 million per year. In summary, the table shows that the main economic activities of people in Chau Thai were mainly livestock farming, plantation forests, and labour activities. Furthermore, it also demonstrates the role of loan policies in economic growth in the area.

Table 2. Farmers' perceived constraints of household livelihood capitals

\begin{tabular}{|c|c|c|c|c|c|c|c|c|c|c|}
\hline \multicolumn{2}{|c|}{$\begin{array}{l}\text { Farmers' } \\
\text { constraints }\end{array}$} & \multirow[t]{2}{*}{$\mathrm{N}$} & \multirow[t]{2}{*}{ Mean } & \multirow{2}{*}{$\begin{array}{l}\text { Std. } \\
\text { Deviati } \\
\text { on }\end{array}$} & \multirow[t]{2}{*}{$\begin{array}{l}\text { Std.Err } \\
\text { or }\end{array}$} & \multirow[t]{2}{*}{ Min } & \multicolumn{2}{|c|}{$\begin{array}{l}95 \% \text { Confidence } \\
\text { Interval for Mean }\end{array}$} & \multirow[t]{2}{*}{ Max } & \multirow[t]{2}{*}{ Range } \\
\hline & & & & & & & $\begin{array}{l}\text { Lower } \\
\text { Bound }\end{array}$ & $\begin{array}{l}\text { Upper } \\
\text { Bound }\end{array}$ & & \\
\hline \multirow[t]{6}{*}{ Land } & $\begin{array}{l}\text { Difficulty with } \\
\text { forestland }\end{array}$ & 215 & 3.25 & 1.27 & 0.09 & 1.0 & 3.08 & 3.42 & 5 & 4 \\
\hline & Small forestland & 215 & 4.20 & 1.07 & 0.07 & 1.0 & 4.05 & 4.34 & 5 & 4 \\
\hline & $\begin{array}{l}\text { Poor and infertile } \\
\text { forestland }\end{array}$ & 215 & 2.76 & 1.34 & 0.09 & 1.0 & 2.58 & 2.94 & 5 & 4 \\
\hline & Faraway location & 215 & 2.69 & 1.45 & 0.10 & 1.0 & 2.49 & 2.88 & 5 & 4 \\
\hline & Steep & 215 & 3.94 & 1.08 & 0.07 & 1.0 & 3.80 & 4.09 & 5 & 4 \\
\hline & $\begin{array}{l}\text { Not reassured to } \\
\text { cultivate }\end{array}$ & 215 & 2.67 & 1.58 & 0.11 & 1.0 & 2.46 & 2.89 & 5 & 4 \\
\hline \multirow[t]{4}{*}{ Loan } & $\begin{array}{l}\text { Difficult to access } \\
\text { loans (from banks, } \\
\text { friends,etc.) }\end{array}$ & 110 & 2.35 & 1.26 & 0.12 & 1.0 & 2.11 & 2.58 & 5 & 4 \\
\hline & Little loan available & 110 & 3.00 & 1.76 & 1.28 & 1.0 & 2.76 & 3.24 & 5 & 4 \\
\hline & Short loan period & 110 & 3.35 & 1.06 & 0.10 & 1.0 & 3.14 & 3.55 & 5 & 4 \\
\hline & High interest rate & 109 & 3.26 & 1.09 & 0.10 & 1.0 & 3.05 & 3.46 & 5 & 4 \\
\hline
\end{tabular}




\begin{tabular}{|c|c|c|c|c|c|c|c|c|c|c|}
\hline & Little or no capital & 164 & 3.90 & 1.08 & 0.08 & 1.0 & 3.74 & 4.07 & 5 & 4 \\
\hline \multirow[t]{6}{*}{ Labor } & $\begin{array}{l}\text { Difficulty with } \\
\text { human resources }\end{array}$ & 215 & 3.70 & 1.122 & 0.08 & 1.0 & 3.55 & 3.85 & 5 & 4 \\
\hline & $\begin{array}{l}\text { Small number of } \\
\text { workers in the } \\
\text { family }\end{array}$ & 215 & 3.86 & 1.09 & 0.07 & 1.0 & 3.71 & 4.01 & 5 & 4 \\
\hline & Poor health & 215 & 3.39 & 1.24 & 0.08 & 1.0 & 3.22 & 3.56 & 5 & 4 \\
\hline & Poor education & 215 & 3.67 & 1.20 & 0.08 & 1.0 & 3.51 & 3.84 & 5 & 4 \\
\hline & $\begin{array}{l}\text { Little experience } \\
\text { and knowledge }\end{array}$ & 215 & 3.60 & 1.17 & 0.08 & 1.0 & 3.45 & 3.76 & 5 & 4 \\
\hline & $\begin{array}{l}\text { A fragile } \\
\text { relationship with } \\
\text { people around }\end{array}$ & 215 & 3.27 & 1.27 & 0.09 & 1.0 & 3.10 & 3.45 & 5 & 4 \\
\hline \multirow[t]{6}{*}{$\begin{array}{l}\text { Reven } \\
\text { ue }\end{array}$} & $\begin{array}{l}\text { Difficult to sell } \\
\text { forest products }\end{array}$ & 215 & 2.64 & 1.397 & 0.10 & 1.0 & 2.45 & 2.83 & 5 & 4 \\
\hline & $\begin{array}{l}\text { Unclear prices of } \\
\text { forest products }\end{array}$ & 215 & 3.53 & 1.37 & 0.09 & 1.0 & 3.35 & 3.72 & 5 & 4 \\
\hline & $\begin{array}{l}\text { Unstable and } \\
\text { volatile prices of } \\
\text { forest products }\end{array}$ & 215 & 3.96 & 1.00 & 0.07 & 1.0 & 3.82 & 4.09 & 5 & 4 \\
\hline & $\begin{array}{l}\text { Low prices of forest } \\
\text { products }\end{array}$ & 215 & 3.70 & 1.15 & 0.08 & 1.0 & 3.55 & 3.86 & 5 & 4 \\
\hline & $\begin{array}{l}\text { Hard bargain from } \\
\text { wholesalers }\end{array}$ & 215 & 2.73 & 1.48 & 0.10 & 1.0 & 2.53 & 2.93 & 5 & 4 \\
\hline & $\begin{array}{l}\text { Weak } \\
\text { manufacturers } \\
\text { market }\end{array}$ & 51 & 2.84 & 1.16 & 0.16 & 1.0 & 2.52 & 3.17 & 5 & 4 \\
\hline
\end{tabular}

Table 2 provides a comparison of residents' assessment of the limitations in planting forest in Chau Thai commune. The table delineates four groups of categories, including land, loan, labor, and income [8]. Although forest plays an important role in households' livelihoods, the methods of exploring and harnessing forestland for the good of their family as a whole are major 
challenges, rated $3.25 / 5$, due to a small area, degraded land, steep slopes, arable land far from farm home and land without Land Ownership Certificate. Statistics indicate that most interviewees shared the opinion that the area of forestland is too small for the family to cultivate, at 4.18/5. This rate could be partly explained through Table 1 when the range was 12.34 hectares, demonstrating an uneven distribution of land.

Moreover, people in Chau Thai commune faced many difficulties in taking out loans. Despite easy access to loans, the mean values from 3.00 to $3.35 / 5$ on grounds of short loan repayment period, high interest rate and limited amount of money lent. More importantly, most families had no or little capital. Besides, labor is also an essential factor in the quality of economic development of the region. In Chau Thai, generally, the labour force had many limitations in both quantity and quality. On top of production factors, the market for forest products also posed major obstacles for indigenous households. For example, the statement that prices of forest products were unstable and volatile with the average score is 3.96/5.

Table 3: Differences in livelihood capitals between poor and non-poor households

\begin{tabular}{|c|c|c|c|c|c|c|c|c|c|c|}
\hline \multirow{3}{*}{\multicolumn{2}{|c|}{$\begin{array}{l}\text { Farmers' livelihood } \\
\text { strategies }\end{array}$}} & \multicolumn{2}{|c|}{$\begin{array}{l}\text { Levene's Test } \\
\text { for Equality of } \\
\text { Variances }\end{array}$} & \multicolumn{7}{|c|}{ T-test for Equality of Means } \\
\hline & & \multirow[t]{2}{*}{$\mathrm{F}$} & \multirow[t]{2}{*}{ Sig. } & \multirow[t]{2}{*}{$\mathrm{t}$} & \multirow[t]{2}{*}{$d f$} & \multirow{2}{*}{$\begin{array}{c}\text { Sig. } \\
\text { (2-tailed) }\end{array}$} & \multirow[t]{2}{*}{$\begin{array}{l}\text { Mean } \\
\text { differen } \\
\text { ce }\end{array}$} & \multirow[t]{2}{*}{$\begin{array}{l}\text { Std. } \\
\text { Error } \\
\text { Differe } \\
\text { nce }\end{array}$} & \multicolumn{2}{|c|}{$\begin{array}{c}95 \% \\
\text { Confidence } \\
\text { Interval of the } \\
\text { Difference }\end{array}$} \\
\hline & & & & & & & & & Lower & Upper \\
\hline \multirow{2}{*}{$\begin{array}{l}\text { Land } \\
\text { use }\end{array}$} & Total area (ha) & 18.46 & 0.00 & 3.99 & 213.00 & 0.00 & 1.59 & 0.35 & 0.90 & 2.28 \\
\hline & $\begin{array}{l}\text { Wet rice land area } \\
\text { (ha) }\end{array}$ & 0.01 & 0.93 & 0.37 & 213.00 & 0.71 & 0.00 & 0.01 & -0.01 & 0.02 \\
\hline
\end{tabular}




\begin{tabular}{|c|c|c|c|c|c|c|c|c|c|c|}
\hline & $\begin{array}{l}\text { Paddy rice land } \\
\text { area (ha) }\end{array}$ & 3.54 & 0.06 & 0.93 & 213.00 & 0.35 & 0.02 & 0.02 & -0.02 & 0.06 \\
\hline & $\begin{array}{l}\text { Shifting cultivation } \\
\text { land area (ha) }\end{array}$ & 2.44 & 0.12 & 0.77 & 213.00 & 0.44 & 0.01 & 0.01 & -0.02 & 0.04 \\
\hline & $\begin{array}{l}\text { Garden land area } \\
\text { (ha) }\end{array}$ & 0.79 & 0.37 & 0.53 & 213.00 & 0.60 & 0.00 & 0.01 & -0.01 & 0.01 \\
\hline & $\begin{array}{l}\text { Forestland area } \\
\text { (ha) }\end{array}$ & 16.82 & 0.00 & 3.86 & 213.00 & 0.00 & 1.51 & 0.34 & 0.83 & 2.19 \\
\hline & Pond land area (ha) & 5.17 & 0.02 & 1.49 & 213.00 & 0.14 & 0.02 & 0.01 & -0.01 & 0.04 \\
\hline & $\begin{array}{l}\text { Residential land } \\
\text { area (ha) }\end{array}$ & 1.92 & 0.17 & 1.00 & 213.00 & 0.32 & 0.01 & 0.01 & -0.01 & 0.03 \\
\hline & $\begin{array}{l}\text { Other land area } \\
\text { (ha) }\end{array}$ & 2.11 & 0.15 & 0.73 & 213.00 & 0.47 & 0.01 & 0.02 & -0.02 & 0.05 \\
\hline Loan & $\begin{array}{l}\text { Taking out a loan } \\
\text { from banks for } \\
\text { production }\end{array}$ & 0.95 & 0.33 & 1.64 & 213.00 & 0.10 & 0.12 & 0.07 & -0.02 & 0.26 \\
\hline & $\begin{array}{l}\text { Borrowing money } \\
\text { from friends for } \\
\text { production }\end{array}$ & 0.82 & 0.37 & 0.44 & 213.00 & 0.66 & 0.03 & 0.07 & -0.11 & 0.17 \\
\hline Labor & $\begin{array}{l}\text { Number of family } \\
\text { members }\end{array}$ & 10.41 & 0.00 & -4.08 & 213.00 & 0.00 & -0.88 & 0.24 & -1.36 & -0.40 \\
\hline & Number of males & 4.31 & 0.04 & -2.59 & 213.00 & 0.01 & -0.39 & 0.16 & -0.71 & -0.07 \\
\hline & Number of females & 11.87 & 0.00 & -3.21 & 213.00 & 0.00 & -0.48 & 0.17 & -0.80 & -0.15 \\
\hline & $\begin{array}{l}\text { Number of working } \\
\text { people }\end{array}$ & 1.02 & 0.31 & -0.69 & 213.00 & 0.49 & -0.11 & 0.15 & -0.40 & 0.19 \\
\hline $\begin{array}{l}\text { Social } \\
\text { relati } \\
\text { onshi } \\
\mathrm{p}\end{array}$ & $\begin{array}{l}\text { Holding position in } \\
\text { a local organization }\end{array}$ & 5.31 & 0.02 & 1.12 & 213.00 & 0.27 & 0.05 & 0.05 & -0.04 & 0.14 \\
\hline $\begin{array}{l}\text { Reven } \\
\text { ue }\end{array}$ & $\begin{array}{l}\text { Total income } \\
\text { (million Dong) }\end{array}$ & 23.60 & 0.00 & 9.64 & 213.00 & 0.00 & 46.42 & 3.81 & 38.90 & 53.95 \\
\hline & $\begin{array}{l}\text { From rice (million } \\
\text { Dong) }\end{array}$ & 1.13 & 0.29 & 0.91 & 213.00 & 0.36 & 0.44 & 0.48 & -0.51 & 1.39 \\
\hline & $\begin{array}{l}\text { From corn (million } \\
\text { Dong) }\end{array}$ & 3.79 & 0.05 & -0.99 & 213.00 & 0.33 & -0.04 & 0.04 & -0.13 & 0.04 \\
\hline
\end{tabular}




\begin{tabular}{|c|c|c|c|c|c|c|c|c|c|}
\hline $\begin{array}{l}\text { From potato } \\
\text { (million Dong) }\end{array}$ & 0.46 & 0.50 & -0.35 & 213.00 & 0.72 & -0.01 & 0.03 & -0.06 & 0.04 \\
\hline $\begin{array}{l}\text { From cassava } \\
\text { (million Dong) }\end{array}$ & 0.76 & 0.38 & 0.43 & 213.00 & 0.67 & 0.02 & 0.04 & -0.06 & 0.10 \\
\hline $\begin{array}{l}\text { From soybean } \\
\text { (million Dong) }\end{array}$ & 4.08 & 0.04 & 1.00 & 213.00 & 0.32 & 0.07 & 0.07 & -0.07 & 0.21 \\
\hline $\begin{array}{l}\text { From fruit (million } \\
\text { Dong) }\end{array}$ & 7.44 & 0.01 & 1.45 & 213.00 & 0.15 & 1.26 & 0.86 & -0.45 & 2.96 \\
\hline $\begin{array}{l}\text { From livestock } \\
\text { (million Dong) }\end{array}$ & 13.34 & 0.00 & 3.55 & 213.00 & 0.00 & 8.74 & 2.03 & 4.74 & 12.74 \\
\hline $\begin{array}{l}\text { From seafood } \\
\text { (million Dong) }\end{array}$ & 5.03 & 0.03 & 1.22 & 213.00 & 0.22 & 0.26 & 0.21 & -0.16 & 0.68 \\
\hline $\begin{array}{l}\text { From forest (million } \\
\text { Dong) }\end{array}$ & 24.03 & 0.00 & 3.49 & 212.00 & 0.00 & 7.45 & 1.75 & 4.00 & 10.90 \\
\hline $\begin{array}{l}\text { From NTFPs } \\
\text { (million Dong) }\end{array}$ & 2.08 & 0.15 & 0.72 & 213.00 & 0.47 & 0.04 & 0.06 & -0.07 & 0.16 \\
\hline $\begin{array}{l}\text { From wages } \\
\text { (labour) (million } \\
\text { Dong) }\end{array}$ & 24.90 & 0.00 & 6.70 & 213.00 & 0.00 & 26.24 & 3.13 & 20.08 & 32.40 \\
\hline $\begin{array}{l}\text { From doing } \\
\text { business (million } \\
\text { Dong) }\end{array}$ & 8.50 & 0.00 & 1.45 & 213.00 & 0.15 & 1.24 & 0.86 & -0.45 & 2.94 \\
\hline $\begin{array}{l}\text { From official salary } \\
\text { (million Dong) }\end{array}$ & 4.41 & 0.04 & 1.05 & 213.00 & 0.29 & 1.12 & 1.07 & -0.98 & 3.22 \\
\hline $\begin{array}{l}\text { From pension } \\
\text { (million Dong) }\end{array}$ & 0.24 & 0.62 & -0.28 & 213.00 & 0.78 & -0.29 & 1.02 & -2.30 & 1.72 \\
\hline
\end{tabular}

Table 3 compares and contrasts two groups of households concerning income levels in Chau Thai, Nghe An. Overall, these groups bore little resemblance to each other when taking the area of land, loan getting, family workforce, and income sources into consideration. First, the income gap between poor and non-poor households was relatively high, at approximately VND50 million per month. This disparity mainly came from plantations, labor, livestock farming, and crop 
cultivation. The most significant difference was in wage earnings, at VND26.24 million, generating VND18.79 million greater than the second-main income source - planted forests. The information on the role of forests could be partly explained by the fact that the area of forest owned by each group was different. According to presented statistics, the average land area of non-poor households was much larger than that of their poor counterpart regarding all types of land surveyed. A gap of 1.51 ha in forestland made the most significant contribution to this difference.

Moreover, revenue from plantation forests (Table 1) also made up a significant proportion, contributing to the overall income gap. Another factor was the number of members in a family.

On average, poor households have 0.88 person more than non-poor ones. On the contrary, the ratio of workers generating income did not differ much between the two groups. According to Table 1, loans played a vital role in local people's economic development when around $50 \%$ of respondents get involved in it. However, non-poor households opted for a bank loan $12 \%$ more than their poor counterparts. In summary, poor and non-poor households in Chau Thai Commune showed enormous variations in several aspects, mainly in land ownership and total revenue.

\section{Experimental Design, Materials, and Methods}

Experimental design: We employed the probability sample approach to make inferences beyond the sample in this study. Accordingly, we selected Chau Thai Commune as a study area for data collection due to two reasons. First, Chau Thai is one of 206 poor communes in Nghe An [9]. Second, with the current forestland available, the commune has a high potential for afforestation, along with projects on climate change mitigation $[10,11]$. After consulting local 
authorities about representative villages, we selected 4 villages: Dong Minh, Ban Hat, Thai Quang, Dong Hin.

Methods: We conducted a survey in 2018 to obtain data on farmers' livelihoods and perceptions of difficulties towards the dimensions of livelihood capitals. We followed three steps in designing our study. First, we formed a focus group to help interviewers grasp the data collection procedure and enhance the questionnaire with the aid of the focus group members [9]. Second, we ran a pilot survey with a view to making proper adjustment to the questionnaire until the final version came out, with a total of 62 questions. The first part of the questionnaire, with 9 questions, investigates the households' land use structure. The second part, 15 questions, looks into income structure. Next is people's perceptions towards setbacks in production forest planting, with 23 questions. The last part, with 15 questions, aims to collect the respondents' personal information and socio-economic background. Third, we conducted a survey using a random sampling technique and questionnaire-based face-to-face interviews [12,13]. We held a progress check to keep track and hold a meeting with survey team members at the end of each working day during the survey process. As a result, a total of 215 households living in 4 selected villages were interviewed. The data were then entered, converted to .xlsx format and coded for further analysis.

To capture the features of the respondents' livelihood and their perceptions towards the constraints presented in Table 1-2, we employed descriptive statistics to obtain results of Mean, Standard deviation, Standard error, Minimum and Maximum values, and Range. Furthermore, we also ran a One-sample T-test to obtain a Confidence Interval for Mean (95\%). Regarding Table 
3, we compare means via Independent Sample T-test, including Levene's Test for Equality of Variances and T-test for Equality of Means, with Confidence Interval of the Difference being 95\%. It is noted that households are categorized into poor and non-poor according to Vietnam's poverty line in rural areas between 2016 and 2020 (US\$1.02 per person/day) [14,15]. The rationale lies with the fact that the impoverished is the research target and this way of categorization facilitates comparison between these two groups. We could explore the differences in land and income structure, demographic features, and perceptions.

As for this research, there is still room for improvement, and acknowledgement of the limitations allows the research quality to improve. [16]. First, the sample size is only 215 households, which means that its confidence level is just above $85 \%$, and the error level is $5 \%$ (Table 4). However, for normally distributed data, 30 or more observations are needed to have reasonably short confidence bounds on the variance estimate. Thus, our size could be deemed big enough to undergo data processing and analysis. Second, the study region is in a poor and mountainous commune where the literacy level of the interviewees is limited, causing difficulties for interviewers to some degree. In addition, rural household livelihood associated with forest development is influenced by many socio-economic factors, especially environmental and cultural values $[17,18]$. Yet, its absence is a limitation of research and should be considered in future studies.

Table 4: Minimum sample size at various confidence and error levels 


\begin{tabular}{llllll}
\hline Confidence level & & $80 \%$ & $85 \%$ & $90 \%$ & $95 \%$ \\
\hline $\begin{array}{lllll}\text { Error } \\
\text { level }\end{array}$ & $1.0 \%$ & 4096 & 5148 & 6766 & 9604 \\
& $2.0 \%$ & 1024 & 1296 & 1692 & 2401 \\
& $3.0 \%$ & 456 & 576 & 752 & 1068 \\
& $4.0 \%$ & 256 & 324 & 423 & 601 \\
& $5.0 \%$ & 164 & 208 & 271 & 385 \\
& $7.5 \%$ & 73 & 93 & 121 & 171 \\
\hline
\end{tabular}

\section{Ethics Statement}

The authors declare that this study is designed for the purpose of research and goodwill. Interviews are conducted on the basis of willingness and mutual consent, and participants' personal information remain confidential.

\section{Supplementary material}

Supplementary material associated with this article can be found in the online version at http://dx.doi.org/10.17632/7bf279kgfg.1

\section{Declaration of Competing Interest}

The authors declare that they have no known competing financial interests or personal relationships that could have influenced the work reported in this paper.

\section{Acknowledgements}


We are deeply thankful to all the people who supported and or participated in this study.

\section{References}

[1] N.T. Lam, Biosphere Reserve in the West of Nghe An: Asserting the brand to the world. Available online at: https://baonghean.vn/khu-du-tru-sinh-quyen-mien-tay-nghe-ankhang-dinh-thuong-hieu-voi-the-gioi-163293.html (accessed on 22 January 2021), Bao Nghe An. (2017).

[2] P. Huong, Efforts to reduce emissions and improve forest economic efficiency in Nghe An. Available online at: https://e.baonghean.vn/no-luc-giam-phat-thai-va-nang-hieu-quakinh-te-rung-o-nghe-an/ (accessed on 22 January 2021), Bao Nghe An. (2020).

[3] P. Huong, Forestry Nghe An: Difficulties, challenges and motivation to develop in the new period. Available online at: https://e.baonghean.vn/no-luc-giam-phat-thai-va-nang-hieuqua-kinh-te-rung-o-nghe-an/ (accessed on 22 January 2021), Bao Nghe An. (2020).

[4] D. Minh, Promote sustainable forest development. Available online at: https://baovemoitruong.org.vn/day-manh-phat-trien-rung-ben-vung/ (accessed on 22 January 2021), Bao Nhan Dan. (2020).

[5] S. Mai, Western Nghe An Biosphere Reserve: Conservation and development. Available online at: https://nongnghiep.vn/khu-du-tru-sinh-quyen-mien-tay-nghe-an-bao-tonphat-trien-d207856.html (accessed on 22 January 2021), Bao Nong Nghiep Nghe An. (2021).

[6] Q. Van Khuc, T.A.T. Le, T.H. Nguyen, D. Nong, B.Q. Tran, P. Meyfroidt, T. Tran, P.B. Duong, 
T.T. Nguyen, T. Tran, L. Pham, S. Leu, N.T. Phuong Thao, N. Huu-Dung, T.K. Dao, N. Van Hong, B.T. Minh Nguyet, H.S. Nguyen, M.W. Paschke, Forest cover change, households' livelihoods, trade-offs, and constraints associated with plantation forests in poor uplandrural landscapes: Evidence from north central Vietnam, Forests. 11 (2020). https://doi.org/10.3390/F11050548.

[7] PM, Decision No 582/QĐ-TTg: Approving the List of Special Difficulty Communes Within Area III, Area II, Area I in Ethnic Minority and Mountainous Region in 2016-2020. Available online at: http://vbpl.vn/TW/Pages/vbpqtoanvan.aspx?|temID=92948\&dvid=13\&fbclid=I, 2017.

[8] W. Solesbury, Sustainable Livelihoods : A Case Study of the Evolution of DFID Policy London, Overseas Dev. Inst. 111 Westminster Bridg. Road London. (2003).

[9] PM, Decision No 582/QĐ-TTg: Approving the List of Special Difficulty Communes Within Area III, Area II, Area I in Ethnic Minority and Mountainous Region in 2016-2020, 2017.

[10] P. Meyfroidt, E.F. Lambin, The causes of the reforestation in Vietnam, Land Use Policy. 25 (2008) 182-197. https://doi.org/10.1016/j.landusepol.2007.06.001.

[11] JICA, The Study on Potential Forests and Land Related to "Climate Change and Forests" in The Socialist Republic of Vietnam, Hanoi, Vietnam, 2012.

[12] Kennethe D. Bailey, Methods of Social Research, fourth ed., The Free Press, New York, USA., 1994.

[13] Sylvie D. Lambert \& Carmen G. Loiselle, Combining individual interviews and focus groups to enhance data, J. Adv. Nurs. (2008) 228-237. https://doi.org/10.1111/j.13652648.2007.04559.x. 
[14] N. Van Tuan, Scientific research handbook - From idea to publication, Ho Chi Minh City Publishing House, 2018.

[15] PM, No. 59/2015 / QD-TTg. Regarding the promulgation of multidimensional poverty lines applicable in the period 2016 - 2020. Available online at: http://vbpl.vn/TW/Pages/vbpqtoanvan. aspx?ItemID=92948\&dvid=13\&fbclid=IwAR21 nxtmjKCkX144a0s4FokNrwShTLsSZ OIRF7gBk, 2015.

[16] Q.H. Vuong, Reform retractions to make them more transparent, Nature. 582 (2020) 149. https://doi.org/10.1038/d41586-020-01694-x.

[17] Q.-H. Vuong, The semiconducting principle of monetary and environmental values exchange (In press), Econ. Bus. Lett. (2021).

[18] Q. Van Khuc, Q.-H. Vuong, Environmental cultural value and global environmental change: By nature, of nature, for nature, OSF Prepr. (2020) 1-13. https://doi.org/10.31219/osf.io/xzsjg. 